\title{
UNSUR BUDAYA DAN NILAI MORAL DALAM CERITA RAKYAT KOMERING SEHARUK: SEBUAH TINJAUAN SOSIOLOGI SASTRA
}

\author{
CULTURAL ELEMENTS AND MORAL VALUES IN THE KOMERING FOLKLORE \\ SEHARUK: A STUDY OF LITERARY SOCIOLOGY
}

\author{
Iing Sunarti; Dedi Febriyanto; Mulyanto Widodo
}

\author{
Magister Pendidikan Bahasa dan Sastra Indonesia \\ Fakultas Keguruan dan Ilmu Pendidikan, Universitas Lampung \\ Jalan Sumantri Brodjonegoro, Gedong Meneng, Bandar Lampung, Indonesia \\ iingsunarti58@gmail.com; dedifebri97@gmail.com; mulyanto.widodo@gmail.com
}

(Naskah diterima tanggal 23 September 2021, direvisi terakhir tanggal 21 Oktober 2021, dan disetujui tanggal 8 November 2021)

DOI: https:/ / doi.org/10.26499/wdprw.v49i2.898

\begin{abstract}
This study aims to explore and describe the cultural elements and moral values contained in the Komering Seharuk folklore. This study used a qualitative descriptive method with a sociological literature approach. The research data source is in the form of Komering Seharuk folklore written by Usman Nurdin. Through these data sources, research data is obtained in the form of sentence quotations collected through the reading-note technique. The analysis of the research data was carried out using content analysis techniques. The results showed that the Komering Seharuk folklore contains elements of Komering culture and quite diverse moral values. The Komering cultural elements in question include; (1) the use of the Komering language, (2) the adoption of the Komering Umbai Akas folk song, (3) the background of the Komering river as one of the cultural sources of the Komering people, and (4) Tala Balak which is used as a means of destroying the tyranny of the authorities. The moral values in question include; (1) obedience, (2) wisdom, (3) willingness to take responsibility, (4) hard work, (5) religiosity, (6)optimism, (7) social care, and (8) peace-loving. The cultural elements and moral values contained in the folklore of Komering Seharuk can be used as a motivational guide for social life.
\end{abstract}

Keywords: cultural elements; moral values; Seharuk

\begin{abstract}
Abstrak
Penelitian ini bertujuan menggali dan mendeskripsikan unsur budaya dan nilai moral yang terkandung dalam cerita rakyat Komering Seharuk. Penelitian ini menggunakan metode deskriptif kualitatif dengan pendekatan sosiologi sastra. Sumber data penelitian berupa cerita rakyat Komering Seharuk yang ditulis oleh Usman Nurdin. Melalui sumber data tersebut diperoleh data penelitian berwujud kutipan kalimat yang dikumpulkan melalui teknik baca-catat. Adapun analisis terhadap data penelitian dilakukan menggunakan teknik analisis isi. Hasil penelitian menunjukkan bahwa cerita rakyat Komering Seharuk mengandung unsur budaya Komering dan nilai moral yang cukup beragam. Unsur budaya Komering yang dimaksud meliputi; (1) penggunaan bahasa Komering, (2) pengangkatan lagu daerah Komering Umbai Akas, (3) latar Sungai Komering sebagai salah satu sumber kebudayaan masyarakat Komering, dan (4) Tala Balak yang digunakan sebagai sarana penghancur kelaliman penguasa. Adapun nilai-nilai moral yang dimaksud meliputi; (1) kepatuhan, (2) kebijaksanaan, (3) kesediaan bertanggung jawab, (4) bekerja keras, (5) religiusitas, (6)
\end{abstract}


optimisme, (7) peduli sosial, dan (8) cinta damai. Unsur budaya dan nilai moral yang terkandung di dalam cerita rakyat Komering Seharuk dapat dijadikan salah satu pedoman dan motivasi dalam kehidupan bermasyarakat.

Kata-kata Kunci: unsur budaya; nilai moral; Seharuk

\section{Pendahuluan}

Cerita rakyat merupakan bagian dari sastra lisan yang hidup di tengah masyarakat. Cerita rakyat sebagai sebuah produk dari masyarakat banyak menggambarkan kebudayaan lokal yang luhur. Triyanto (2014: 35) mengungkapkan bahwa kebudayaan merupakan keseluruhan cara hidup. Budaya merupakan makna dan nilai kehidupan sehari-hari yang merupakan bagian dari totalitas ekspresif hubunganhubungan sosial. Suatu kebudayaan selalu menandakan adanya proses berpikir yang dilandasi semangat hidup masyarakatnya (Irawati, 2015: 54). Proses berpikir tersebut selanjutnya akan membentuk suatu keyakinan di dalam masyarakat mengenai segala hal yang dipandang sebagai sebuah kebenaran.

Cerita rakyat juga dipandang sebagai kekayaan milik rakyat yang kehadirannya adalah untuk menciptakan sebuah hubungan sosial antarmanusia. Dalam cerita rakyat dapat dilihat adanya berbagai tindakan berbahasa, guna menampilkan adanya nilai-nilai dalam masyarakat (Semi, 1993: 79).

Di antara beragam nilai yang terkandung dalam cerita rakyat, nilai moral adalah salah satu di antaranya. Nilai merupakan suatu yang dipandang penting dan baik, semacam keyakinan seseorang terhadap yang seharusnya atau tidak seharusnya dilakukan, sedangkan moral berkaitan dengan perasaan terhadap tindakan yang dilakukan diri sendiri (Zakiyah \& Rusdiana, 2014: 14).
Nurgiyantoro (2015: 433) mengungkapkan bahwa moral cerita biasanya dimaksudkan sebagai suatu saran yang berhubungan dengan ajaran moral tertentu yang bersifat praktis. Ia merupakan petunjuk yang sengaja diberikan oleh pengarang tentang berbagai hal yang berhubungan dengan tingkah laku dan sopan santun pergaulan.

Penelitian ini memfokuskan kajian pada unsur budaya dan nilai moral yang terkandung dalam cerita rakyat. Fokus tersebut dipilih atas dasar keinginan peneliti untuk mengeksploitasi budaya-budaya Komering yang ada di dalam cerita rakyatnya. Selain itu, dengan mengkaji nilai moral akan diperoleh pula pemaha-man secara mendalam berkenaan dengan cara pandang masyarakat Komering dalam memahami nilai-nilai kebenaran.

Adapun cerita rakyat yang menjadi sumber kajian dalam penelitian ini adalah cerita rakyat Komering Seharuk yang ditulis oleh Usman Nurdin. Cerita rakyat yang dimaksud diterbitkan pada 2021 oleh Penerbit Intishar Publishing. Pemilihan cerita rakyat Komering Seharuk sebagai objek penelitian didasarkan pada kesadaran akan pentingnya menjaga warisan budaya bangsa khususnya di bidang kesusastraan. Penggalian serta publikasi kembali cerita rakyat Komering merupakan langkah awal yang dapat dilakukan dalam rangka menjaga warisan budaya bangsa tersebut. Terlebih lagi cerita rakyat merupakan perwujudan dari kekayaan budaya lokal di Indonesia yang harus senantiasa dilestarikan keberadaannya. 
Kisah Seharuk sangat melekat dalam kebudayaan Komering. Seharuk digambarkan sebagai pria jelata yang sangat bersahaja. Ia tinggal di daerah Uluan wilayah Kesultanan Palembang. Setelah orangtuanya meninggal, Seharuk tinggal bersama dengan neneknya. Ia dikenal sebagai pemuda jenaka, berbudi luhur, dan sangat menghormati orangtuanya. Cerita tentang Seharuk yang ditulis oleh Usman Nurdin banyak memuat ajaran moral dan unsur budaya Komering. Oleh karena itu, kajian terhadap keduanya (unsur budaya dan nilai moral) dipandang penting oleh peneliti.

Penelitian terdahulu yang memiliki relevansi dengan penelitian saat ini di antaranya pernah dilakukan oleh Pahruroji dkk. (2019) yang mengangkat judul, "Nilai moral pada Cerpen Misteri Uang Melayang Karya Sona. Hasil penelitian menunjukkan bahwa cerpen yang dianalisis mengandung nilai moral di antaranya pantang menyerah, rela berkorban tanpa pamrih, kerja keras, kreatif, saling memaafkan, tidak berbuat licik dan curang demi mendapatkan sesuatu. Penelitian relevan berikutnya dilakukan oleh Sa'ida (2020) dengan judul, "Analisis Nilai Moral dalam Cerita Rakyat". Hasil penelitian menunjukkan bahwa cerita rakyat mengandung nilainilai moral di antaranya jujur, penolong, sopan, hormat, membedakan perilaku baik dan buruk.

Penelitian relevan berikutnya dilakukan oleh Dwiyanti \& Suherman (2019) dengan mengangkat judul, "Unsur Budaya dalam Cerita Film Cakra Buana Karya Sutradara Massimo Burhanuddin". Berdasarkan penelitian, diketahui bahwa film Cakra Buana mengandung unsur-unsur budaya di antaranya tentang sistem religi, sistem mata pencaharian, sistem pengetahuan, teknologi, hingga sistem kesenian. Topik yang sama juga dikaji oleh Herdianawati \& Isnaniah (2020) dengan judul, “Unsur
Budaya dalam Kumpulan Cerpen Martabat Kematian Karya Muna Mastari sebagai Bahan Ajar BIPA". Hasil penelitian menunjukkan bahwa Kumpulan Cerpen Martabat Kematian mengandung unsur-unsur budaya Madura yang dapat dijadikan sebagai bahan ajar dan penunjang keterampilan berbahasa pembelajar BIPA.

Penelitian terdahulu yang telah disebutkan memiliki relevansi dengan penelitian saat ini ditinjau dari fokus penelitian, yaitu unsur budaya dan nilai moral. Meskipun demikian, pada kajian unsur kebudayaan tentunya akan memunculkan sebuah kebaruan. Hal ini dikarenakan kebudayaan setiap daerah berbeda-beda. Perbedaan paling mendasar terletak pada sumber data penelitian. Jika penelitian terdahulu cenderung menggunakan jenis karya sastra baru, maka penelitian ini memilih karya sastra lama berjenis cerita rakyat sebagai sumber data penelitian.

Bertolak dari pemaparan di atas, penelitian ini dilakukan untuk mengeks-ploitasi dan mendeskripsikan unsur budaya dan nilai moral yang terkandung dalam cerita rakyat Komering Seharuk. Hasil penelitian diharapkan dapat memperkaya literatur kesusastraan lokal sekaligus menjadi salah satu pedoman penerapan nilai moral di tengah kehidupan bermasyarakat.

\section{Budaya}

Budaya atau kebudayaan secara etimologi berasal dari bahasa sansekerta, buddhayah dari bentuk jamak buddhi 'budi atau akal' yang diartikan sebagai segala hal berkaitan dengan budi dan akal manusia. Adapun dalam bahasa Inggris, kebudayaan disebut culture yang berasal dari kata latin colere yaitu mengolah atau mengerjakan, dapat diartikan juga sebagai mengolah tanah atau bertani. Kata culture juga kadang sering diterjemahkan sebagai "Kultur" da- 
lam bahasa Indonesia (Muhaimin dalam Sumarto, 2019: 145).

Kultur atau kebudayaan adalah keseluruhan yang kompleks, termasuk di dalamnya adalah pengetahuan, kepercayaan, kesenian, moral, hukum adat, dan segala kemampuan dan kebiasaan lain yang diperoleh manusia sebagai seorang anggota masyarakat (Taylor dalam Sumarto, 2019: 147). Kebudayaan merupakan keseluruhan pengetahuan manusia sebagai makhluk sosial yang digunakan untuk memahami lingkungan serta pengalamannya dan yang menjadi pedoman tingkah lakunya (KBBI, 2014: 215). Adapun Linton (Tasmuji dkk., 2011: 151) mengungkapkan bahwa kebudayaan adalah seluruh cara kehidupan dari masyarakat dan tidak hanya mengenai sebagian tata cara hidup saja yang dianggap lebih tinggi dan lebih diinginkan.

Adapun yang termasuk ke dalam unsur-unsur kebudayaan meliputi; 1) bahasa, 2) sistem pengetahuan, 3) organisasi sosial, 4) sistem peralatan hidup dan teknologi, 5) sistem mata pencaharian, 6) sistem religi, 7) kesenian (Koentjaraningrat 1990: 98).

Bertolak dari pendapat di atas, dapat disimpulkan bahwa kebudayaan merupakan seluruh cara kehidupan masyarakat yang didasarkan pada akal budi. Kebudayaan merupakan segala kegiatan di dalam sebuah masyarakat yang disepakati keberadaannya karena adanya nilai kebaikan di dalamnya. Kesepakatan dalam sebuah masyarakat merupakan syarat mutlak sesuatu tersebut disebut sebagai kebudayaan.

\section{Nilai Moral}

Nilai adalah rujukan dan keyakinan dalam menentukan pilihan. Nilai merupakan sesuatu yang diinginkan sehingga melahirkan tindakan pada diri seseorang (Mulyana, 2004: 11). Nilai merupakan sesuatu yang melekat pada diri manusia yang patut untuk dijalankan dan dipertahankan karena mengandung kebaikan-kebaikan (Sukitman, 2016: 87). Adapun moral merupakan segala perbuatan atau tingkah manusia yang sesuai dengan aturan yang mengatur hukum sosial atau adat (Chaplin, 2006: 407). Selanjutnya, Murti \& Maryani (2017: 52) mengungkapkan bahwa moral adalah perbuatan, tingkah laku, atau ucapan seseorang dalam berinteraksi dengan manusia. Moral adalah setiap tindakan yang mengarap pada hubungan sosial.

Nilai moral dengan demikian dapat disimpulkan sebagai segala sikap individu yang dipandang ideal oleh masyarakat. Sikap, sifat, maupun tindakan yang memberikan kebaikan-kebaikan untuk diri, keluarga, dan masyarakat secara umum.

\section{Cerita Rakyat}

Cerita rakyat merupakan kesusastraan yang berasal dari rakyat yang penyebarannya pada umumnya melalui tutur kata atau lisan (Danandjaja, 2007: 5). Cerita rakyat merupakan cermin kehidupan masyarakat lama yang banyak memuat nilai-nilai moral. Pada umumnya cerita rakyat mengisahkan tentang suatu kejadian di suatu tempat atau asal muasal suatu tempat (Gusnetti dkk., 2015: 184).

Cerita rakyat sebagai sebuah kesusastraan klasik memiliki ciri-ciri khusus. Badudu (Rahmawati, 2012) meng-ungkapkan ciri-ciri karya sastra sebagai berikut: (1) isi cipta sastra yang bersifatfantastis, istana sentris, dan didaktis; (2) bahasanya banyak menggunakan bahasa klise sebagai variasinya; (3) nama-nama pengarang sering tidak disebutkan, sehing-ga hasil sastranya kebanyakan anonim.

Cerita rakyat dengan cirinya yang khas dapat dijadikan sebagai perenungan dan penghayatan kaitannya dengan nilai- 
nilai kehidupan (Maulidiah \& Saddhono, 2019: 187). Hal itu menunjukkan bahwa cerita rakyat sebagai salah satu perwujudan karya sastra tidak hanya berfungsi untuk menghibur pembaca semata. Lebih dari itu, cerita rakyat sebagai sebuah karya sastra juga dapat dijadikan sebagai salah satu bahan perenungan untuk perubahan hidup yang lebih baik.

\section{Metode}

Penelitian ini menggunakan metode deskriptif kualitatif dengan pendekatan sosiologi sastra. Sumber data penelitian berupa cerita rakyat Komering Seharuk yang ditulis oleh Usman Nurdin. Buku tersebut diterbitkan pertama kali oleh pener-bit Intishar Publishing pada Maret 2021. Melalui sumber data tersebut, diperoleh data penelitian berwujud kutipan kalimat yang dikumpulkan melalui teknik baca-catat. Mula-mula peneliti membaca cerita rakyat Komering Seharuk secara cermat dan teliti. Selanjutnya peneliti melakukan pencatatan terhadap data-data yang mengandung unsur budaya dan nilai mo-ral. Adapun analis data dilakukan menggunakan teknik analisis isi. Teknik ini digunakan karena penelitian ini berusaha menggali makna yang terkandung dalam cerita rakyat Komering Seharuk yang berwujud unsur budaya dan nilai moral.

\section{Hasil dan Pembahasan}

\subsection{Unsur Budaya dalam Cerita Rakyat Komering Seharuk}

Cerita rakyat Komering Seharuk yang ditulis oleh Usman Nurdin mengandung unsur budaya Komering yang cukup kental. Unsur budaya yang berhasil ditemukan dalam penelitian ini meliputi penggunaan bahasa daerah Komering, lagu daerah, sistem mata pencaharian, sikap hidup masyarakatnya yang dapat dilihat melalui tokoh utama, dan juga latar sungai Kome-ring sebagai salah satu simbol lahirnya beragam kebudayaan luhur Komering lainnya.

\section{Penggunaan Bahasa Komering}

Bahasa Komering merupakan salah satu bahasa daerah yang terdapat di provinsi Sumatera Selatan. Bahasa Komering sebagai salah satu bahasa yang ada di Indonesia merupakan salah satu pendukung terhadap keutuhan dan perkembangan kebudayaan yang ada.

Penggunaan bahasa Komering dalam cerita rakyat Komering Seharuk cukup kental. Penggunaan bahasa Komering umumnya sering muncul dalam pertuturan yang melibatkan tokoh Nenek Seharuk. Hal ini bisa dilihat melalui kutipan berikut.

"Seharuk, hunja pai niku," ujar nenek Seharuk pagi itu.

"Yu umbai. Wat api?"

"Nyak meretok iwak tamong, seluang buta jadila." (Nurdin, 2021: 21)

Terjemah:

"Seharuk, ke sini dulu," ujar nenek Seharuk pagi itu.

"Ya, Nenek, ada apa?"

"Aku ingin ikan cucung. Ikan seluang buta jadilah." (Nurdin, 2021: 21)

“Umbai ... Umbai ...," suara Seharuk memanggil neneknya.

"Iyu tamong, mansa kudo iwakho, nyak kokbetoh Seharuk nunggu niku."

"Makwat umbai. Nyak mak mangsa seseluang buta sina."

"Yu radu, amon mak mangsa, layon rejeki artinya (Nurdin, 2021: 26).

Terjemah:

"Nenek ... Nenek ...," suara Seharuk memanggil neneknya.

"Iya cucung. Dapat ikannya, aku sudah lapar, Seharuk, nunggu kamu. 
“Tidak, Nek. Saya tidak dapat ikan seluang buta itu."

Ya sudah, kalau tidak dapat bukan rejeki namanya." (Nurdin, 2021: 26)

Kutipan-kutipan di atas menggambarkan penggunaan bahasa Komering oleh tokoh Seharuk bersama neneknya. Penggunaan bahasa Komering sebagaimana terlihat pada data di atas banyak digunakan dalam cerita rakyat Komering Seharuk yang ditulis oleh Usman Nurdin. Penggunaan bahasa Komering tersebut dimaksudkan untuk menguatkan penggambaran kebudayaan Komering sebagai sebuah peradaban yang adiluhung. Selain itu, penggunaan bahasa Komering juga dimaksudkan untuk menggambarkan kesederhanaan dan sikap tokoh-tokoh cerita yang menjunjung tinggi bahasa daerahnya.

\section{Lagu Daerah Komering}

Lagu daerah Komering yang dimunculkan dalam cerita rakyat Seharuk adalah lagu daerah Komering berjudul Umbai Akas. Hal ini bisa dilihat melalui kutipan berikut.

Seiring perjalanan Seharuk menuju sungai Komering, selain berdoa ia bersiul-siul dan bernyanyi riang gembira, diikuti dengan suara burung pahi yang rendah terbang mengikuti langkah perjalanan Seharuk menuju bibir sungai.

"Umbai akas sikamkok haga mulang, Muli meranai basa gincah-gincahan, amon niku kawai handak Nyak kawai handak munih, nyak haga niku munih, nyak haga niku munih," gumam merdu dalam hati seharuk sepagi ini. (Nurdin, 2021: 23).
Lagu Komering Umbai Akas sebagaimana yang tercermin di atas tidak secara utuh dituangkan. Itu hanyalah sebagian besar dari liriknya. Dinyanyikan-nya lagu Umbai Akas oleh Seharuk dikarenakan keadaan hatinya yang sedang riang gembira. Hal itu sejalan dengan makna yang terkandung di dalam lagu Umbai Akas tentang sebuah harapan.

\section{Sungai Komering sebagai Sumber Kebu- dayaan Masyarakat}

Sungai Komering merupakan sumber kehidupan bagi masyarakat Komering. Di sana segala kebudayaan baru muncul dan berkembang. Hikayat Pitu Phuyang sebagai cikal bakal lahirnya suku Komering juga membangun peradaban Wangsa Buay Tumi di mulai dari dataran sungai Komering (Bastari, 2019: 144).

Gemericik suara aliran sungai mulai terdengar. Komering adalah sumber kehidupan kampung Seharuk. Mandi, mencuci, dan lainnya ditopang oleh aliran Komering yang landai (Nurdin, 2021: 23).

Kutipan di atas menggambarkan betapa pentingnya keberadaan sungai Komering bagi masyarakat yang tinggal di sekitar aliran sungai. Bahkan masyarakat seakan memiliki ketergantungan yang kuat terhadap sungai Komering.

Keberadaan sungai Komering juga menciptakan sistem mata pencaharian masyarakatnya. Sungai Komering yang kaya akan keanekaragaman jenis ikannya membuat sebagian besar masyarakat Komering menggantungkan kebutuhan hidupnya pada limpahan hayati yang terkandung di dalam sungai Komering. Hal ini tidak terkecuali dilakukan oleh Seharuk. Ia mencari ikan di sungai Komering untuk memenuhi kebutuhan hidupnya. 
Hari itu ikan yang terperangkap pada bubu Seharuk tidak melimpah seperti biasanya. Dia tidak bisa menjual pada orang lain. Padahal ikan hasil dari bubu yang ia pasang bisa membantu membeli keperluan lainnya (Nurdin, 2021: 23).

Kutipan di atas dengan jelas menggambarkan ketergantungan Seharuk terhadap hasil tangkapan yang biasa ia lakukan di Sungai Komering. Melalui hasil tangkapan dari sungai Komering, Seharuk dapat membeli kebutuhan hidup lainnya. Hal itu juga menunjukkan bahwa sungai Komering mengandung kekayaan hayati yang sangat melimpah.

Keberadaan Sungai Komering telah terbukti dapat melahirkan peradaban luhur dalam sebuah masyarakat khususnya suku Komering. Jika sebuah sungai yang tampak sederhana saja mampu melahirkan kebudayaan luhur, lantas bagaimana dengan wujud kekayaan alam yang jauh lebih besar, tentunya akan membawa pengaruh yang lebih besar pula dalam sebuah masyarakat. Oleh karena itu, masyarakat sudah selayaknya peduli terhadap alam sekitar.

\section{Tala Balak Penghancur Kelaliman Pe- nguasa}

Tala Balak merupakan alat tradisional khas suku Komering yang sekarang sering dipakai untuk acara penyambutan pada acara pernikahan dan pengiring Tari Sada Sabai (Nurdin, 2021: 46).

Tala Balak digunakan Seharuk untuk membalas kezaliman Pasirah terhadap neneknya. Neneknya menjadi korban kekejaman Pasirah dengan dicambuk berkalikali. Melihat neneknya diperlakukan sedemikian kejam, Seharuk tidak terima. Ia pun menyusun sebuah rencana dengan menggunakan Tala Balak tersebut.

Keesokan harinya, Seharuk mencari cara bagaimana menghancurkan Pasirah lalim itu, sementara dia hanya berdua bersama neneknya. Dalam renunannya, dia teringat peninggalan ayahandanya, yaitu Tala Balak, kemudian Seharuk membuat perahu yang cukup banyaknya (Nurdin, 2021:4546).

Tala Balak kalau dia berbunyi pada saat itu menandakan ada keramaian atau ada pesta besar, maka semua orang akan berbondong-bondong mendekatinya untuk mencari hiburan. (Nurdin, 2021: 46).

Dengan menggunakan Tala Balak dan perahu yang telah dibuatnya, Seharuk berhasil mengumpulkan masyarakat dan bergerak menuju ke gedung marga. Bahkan tidak hanya masyarakat, hewanhewan pun turut serta di dalam rombongan yang digerakkan oleh Seharuk. Setalah sampai di tengah perjalanan, Seharuk menyampaikan maksudnya bahwa ia berencana menghancurkan kezaliman Pesirah yang kejam itu. Mendengar maksud Seharuk, masyarakat pun langsung mengamininya, karena mereka juga merasakan penderitaan yang sangat berat akibat kezaliman Pesirah.

Sampai di ilir sungai Komering, tak terasa sampai di sosat marga. Akhirnya tanpa menunggu waktu lama, rombongan Seharuk langsung menyerang Pasirah, hingga pasirah dan para penggawa marga menyerah takluk kepadanya (Nurdin, 2021: 48). 
Data di atas menggambarkan penyerangan oleh rombongan yang dipimpin Seharuk. Karena serangan datang tiba-tiba, Pesirah dan para punggawa banyak yang terluka dan takluk seketika juga. Selanjutnya, Seharuk diangkat menjadi pasirah sementara menggantikan Pasirah kejam yang telah berhasil ditumbangkan.

Alat tradisional Tala Balak dalam cerita Seharuk dapat digunakan sebagai sarana penghimpun kekuatan. Diiringi dengan kecerdasan penggunanya, alat tradisional tersebut dapat menjadi sarana penghancur kelaliman penguasa.

\subsection{Nilai Moral dalam Cerita Rakyat Ko- mering Seharuk}

Berdasarkan kajian yang dilakukan, dapat diketahui bahwa cerita rakyat Komering Seharuk mengandung nilai moral yang cukup kompleks. Nilai-nilai tersebut banyak dimunculkan pengarang melalui sikap tokoh cerita. Adapun nilai-nilai moral yang ditemukan meliputi nilai; (1) kepatuhan, (2) kebijaksanaan, (3) kesediaan bertanggung jawab, (4) bekerja keras, (5) religiusitas, (6) peduli sosial, (7) optimisme, dan (8) cinta damai. Nilai moral yang telah dikemukakan tersebut akan diuraikan sebagai berikut.

\section{Kepatuhan}

\section{Kepatuhan terhadap Pemimpin}

Nilai moral tentang kepatuhan dimunculkan pengarang melalui sikap tokoh yang justru tidak patuh kepada Pasirah, kepala marga di daerahnya. Hal ini dapat dilihat melalui kutipan berikut.

"Hai Seharuk, kau dipanggil Pasirah untuk menghadap," kata utusan Pasirah.

"Buat apa pasirah memanggilku. Aku tidak ada keperluan dengannya," jawab Seharuk dengan entengnya seperti tanpa beban.

"Hai Seharuk, kau tidak boleh berkata seperti itu kepada Pasirah." (Nurdin, 2021: 12)

Kutipan di atas menggambarkan ketidakpatuhan Seharuk kepada Pasirah, kepala marga di daerahnya. Seharuk menolak panggilan Pasirah karena ia mengetahui bahwa tujuan Pasirah memanggilnya adalah untuk mengangkat dirinya menjadi khatib di daerahnya. Adapun di lubuk hatinya yang paling dalam, Seharuk tidak berkenan untuk dijadikan sebagai khatib.

"Katakan kepada Pasirah, aku sudah tahu maka aku tidak mau," kata Seharuk.

“Apa maksudnya Seharuk?" Tanya utusan dengan rasa penasaran.

"Sudah pergi sana. Bilang saja begitu kepada Pasirah." (Nurdin, 2021: 14)

Melalui kutipan tersebut juga dapat disimpulkan bahwa Seharuk merupakan sosok yang tidak gila pangkat dan jabatan. Seharuk lebih tenang menjadi rakyat biasa yang bisa bergerak ke mana saja ia kehendaki. Berbeda halnya ketika Seharuk menerima tawaran dari sang Pesirah, pastilah ia akan hidup dikelilingi peraturanperaturan yang tidak dapat membuatnya hidup bebas.

Melalui kutipan tersebut juga dapat ditarik sebuah penjelasan, bahwa karya sastra sebagai produk masyarakat memiliki beragam cara untuk menyampaikan nilai-nilai kepada pembaca. Tidak semua nilai digambarkan melalui perilaku terpuji dari tokoh cerita, sebagaimana tidak se- 
mua hikmah diperoleh melalui kejadiankejadian yang menyenang-kan.

\section{Kepatuhan kepada yang Lebih Tua}

Kepatuhan terhadap yang lebih tua ditunjukkan oleh Seharuk. Ia adalah sosok yang sangat menghormati dan mematuhi neneknya. Semenjak ditinggal oleh ayahnya, Nenek lah keluarga satu-satunya yang dimiliki Seharuk.

Seharuk adalah anak yang patuh kepada neneknya. Dia tidak pernah menjawab dengan kata-kata kasar. Ia selalu menjawab 'iya' kepada neneknya, karena neneknya adalah satusatunya orang yang dimilikinya. (Nurdin, 2021: 22)

Kutipan di atas menggambarkan kepatuhan Seharuk kepada neneknya. Ia merupakan pribadi santun, penuh kelembutan. Ia tidak pernah berkata-kata kasar kepada neneknya. Seharus selalu meme-nuhi semua yang diinginkan oleh neneknya. Hal ini dilakukan Seharuk karena neneknya adalah satu-satunya keluarga yang dimiliki dan dapat membimbing dirinya.

\section{Kebijaksanaan}

Kebijaksanaan merupakan sikap yang mendayagunakan akal budinya dalam setiap tindakan (Suharso \& Retnoningsih, 2020: 88). Nilai moral tentang kebijaksanaan digambarkan melalui tokoh Pasirah dan Nenek Seharuk.

\section{Sikap Adil Seorang Pemimpin}

Keadilan seorang pemimpin tergambar melalui tokoh Pesirah. Pada bagian lain, Pasirah digambarkan sebagai sosok yang adil terhadap rakyatnya, dalam hal ini adalah Seharuk. Pasirah berkenan mengabulkan permintaan Seharuk karena ia merasa telah merugikan Seharuk. Hal ini bisa dilihat melalui kutipan berikut.

Seharuk berkata, "Tuanku, hamba sudah lelah, sudah mau istirahat, tibatiba diwajibkan hadir di tempat ini, padahal hamba tiada bersalah. Hamba mohon ganti rugi. Sebab jatah waktu istirahat hamba sudah hilang karena panggilan Tuanku. Padahal esok hamba harus mencari nafkah untuk nenek hamba."

Sejenak Pasirah melangak, terkejut atas protes Seharuk, namun tiba-tiba ia tertawa terbahak-bahak, "Hahaha... jangan kuatir Seharuk."

Pasirah kemudian memerintahkan bendahara Marga memberikan sekantong uang perak kepada Seharuk. Seharuk pun pulang dengan hati gembira (Nurdin, 2021: 17-18).

Kutipan di atas menggambarkan wujud keadilan Pasirah kepada Seharuk. Seharuk yang menyampaikan protes keberatan atas segala yang dianggap sa-ngat merugikannya itu rupanya dapat dipahami oleh Pesirah. Hal ini dibuktikan dengan diberikannya Seharuk oleh Pasirah sekantung perak yang tentunya sangat membuat Seharuk bahagia.

Keadilan seorang pemimpin sangat dibutuhkan di dalam setiap aspek kehidupan. Hal ini dikarenakan sikap adil yang dimiliki seorang pemimpin dapat melahirkan kesejahteraan bagi orang-orang yang dipimpinnya. Sebaliknya, hilangnya sikap adil di dalam diri seorang pemimpin akan melahirkan penderitaan bagi orang-orang yang dipimpinnya.

\section{Memberikan Pelajaran Hidup}


Nilai moral kebijaksanaan juga tergambar melalui pemberian pelajaran hidup untuk orang lain. Hal ini digambarkan dalam cerita melalui tokoh Nenek Seharuk.

Dengan penuh kasih sayang, Nenek Seharuk memberikan pelajaran hidup penuh makna kepada cucu tercinta (Nurdin, 2021: 20).

Sebagai satu-satunya keluarga yang dimiliki Seharuk, tokoh nenek sangat teguh dalam menjalankan tanggung jawabnya dalam mendidik cucu tercinta. Nenek selalu memberikan pelajaran berharga kepada Seharuk. Sang nenek juga mengajarkan kepada Seharuk tentang bagaimana cara memaknai sebuah kehidupan melalui segudang permasalahan yang datang menghampiri.

\section{Kesediaan Bertanggung Jawab}

Kesediaan bertanggung jawab merupakan sikap dan perilaku seseorang untuk melaksanakan tugas dan kewajiban yang seharusnya dia lakukan, terhadap diri sendiri, masyarakat, lingkungan (alam, sosial, dan budaya), negara dan Tuhan Yang Maha Esa (Febriyanto \& Suryani, 2020: 19). Nilai moral tentang kesediaan bertanggung jawab dalam cerita dimiliki oleh Pasirah.

Seharuk berkata, "Tuanku, hamba sudah lelah, sudah mau istirahat, tibatiba diwajibkan hadir di tempat ini, padahal hamba tiada bersalah. Hamba mohon ganti rugi. Sebab jatah waktu istirahat hamba sudah hilang karena panggilan Tuanku. Padahal esok hamba harus mencari nafkah untuk nenek hamba."

Sejenak Pasirah melangak, terkejut atas protes Seharuk, namun tiba-tiba ia tertawa terbahak-bahak, "Hahaha... jangan kuatir Seharuk."

Pasirah kemudian memerintahkan bendahara Marga memberikan sekantong uang perak kepada Seharuk. Seharuk pun pulang dengan hati gembira (Nurdin, 2021: 17-18).

Data di atas menggambarkan wujud tanggung jawab dari Pasirah atas perintahnya yang dianggap merugikan Seharuk. Pasirah merasa berkewajiban memberikan ganti rugi kepada Seharuk tersebut. Ganti rugi tersebut diwujudkan Pasirah dengan memberikan sekantong uang perak kepada Seharuk.

\section{Bekerja Keras}

Kerja keras merupakan upaya untuk melakukan secara sesuatunya dengan penuh kesungguhan serta pantang menyerah dalam rangka mencapai sebuah hasil yang maksimal (Harmanti dkk., 2020: 188). Seharuk juga digambarkan sebagai sosok yang pekerja keras. Ia bersama dengan neneknya saling mendukung dan bahumembahu mencari kebutuhan hidup.

Sesampai di sana, Seharuk langsung memasang bubu, tangkul dank ail di sungai. Setelah bubu terpasang dengan baik, Seharuk pun memasang kail di pinggir sungai. Sesudahnya barulah tangkul besar ia persiapkan (Nurdin, 2021: 21).

Kutipan-kutipan di atas dengan jelas menggambarkan sosok Seharuk yang pekerja keras. Ia dengan cekatan melakukan dan mempersiapkan beragam cara menangkap ikan seorang diri. Hal itu dimungkinkan karena itu sudah menjadi kebiasaannya semenjak lama. Selain itu, hal itu dilakukan Seharuk karena kepatuhannya yang tinggi kepada neneknya. 
Bekerja keras merupakan sikap yang selayaknya dimiliki oleh setiap orang, terlebih oleh orang-orang yang mengharapkan kebahagiaan hidup dunia dan akhirat. Sikap bekerja keras yang dimaksudkan di sini adalah sikap bekerja keras dalam segala hal. Tidak hanya sebatas pada bekerja keras untuk memperoleh harta dunia semata. Lebih dari itu, kita juga harus bekerja keras untuk memperbaiki sikap, mental, dan hati kita.

\section{Religiusitas}

Religiusitas merupakan nilai moral yang berkaitan erat dengan kesalehan dan ketaatan seseorang terhadap agamanya (Febriyanto dkk., 2021: 330). Nilai moral berwujud religiusitas digambarkan melalui beragam sikap dan tindakan yang dilakukan tokoh cerita. Salah satu tokoh yang di dalam dirinya tertanam nilai religiusitas adalah Seharuk. Hal ini bisa dilihat melalui kutipan berikut.

Akhirnya Seharuk mencium tangan si nenek, sembari mengharap besar yaitu mendapatkan yang diinginkan oleh neneknya, dengan harapan yang penuh semangat. Seharuk berdoa semoga hari ini dia mendapatkan apa yang diinginkan oleh neneknya (Nurdin, 2021: 22-23).

Nilai religiusitas yang tergambar melalui kutipan di atas diketahui melalui pengharapan Seharuk kepada Tuhan yang maha esa. Seharuk sebagai seorang hamba tak pernah melupakan tirakat. Salah satu wujud tirakatnya adalah melantunkan doa-doa kepada Tuhan agar segala yang diupayakannya dapat membuahkan hasil baik.

Seharuk juga digambarkan sebagai pribadi yang selalu bersyukur kepada Tuhan.
Suatu ketika ada seorang pemuda biasa yang hidup bersama neneknya. Meskipun hidupnya serba kekurangan, mereka selalu bersyukur atas apa yang telah diberikan oleh Tuhan. Pemuda tersebut bernama Seharuk. (Nurdin, 2021: 44).

Data di atas menggambarkan sikap syukur yang selalu diungkapkan oleh Seharuk, sekalipun kehidupannya selalu dalam kekurangan. Seharuk percaya bahwa ada banyak nikmat lain yang jauh lebih besar dan berarti daripada kekurangankekurangan yang dirasakan bersama neneknya.

\section{Peduli Sosial}

Peduli sosial merupakan sikap dan tindakan yang selalu ingin memberi bantuan pada orang lain dan masyarakat yang membutuhkan (Hartono, 2014: 263). Kepedulian sosial dalam cerita tergambar melalui tokoh utama cerita, Seharuk. Ia adalah sosok yang memiliki kepedulian sosial tinggi. Hal ini bisa dilihat melalui kutipan berikut.

Keesokan harinya, setelah kejadian seluang buta, Seharuk menjalankan aktifitasnya seperti sedia kala, membantu neneknya mencari bahan makanan di hutan, mencari kayu bakar, dan lainnya (Nurdin, 2021: 27).

Kutipan di atas menggambarkan kepedulian sosial Seharuk kepada neneknya. Ia selalu membantu neneknya mencari bahan makanan dan kayu bakar di dalam hutan. Ia tidak tega jika harus melihat neneknya bekerja sendirian dalam memenuhi kebutuhan hidup keluarganya.

Kepedulian sosial Seharuk juga tergambar ketika ia di suatu hari mendengar seseorang berteriak meminta pertolongan. 
Hal ini bisa disimak melalui kutipan berikut.

Sesampainya di bibir aliran sungai, senyap terdengar suara seseorang yang meminta pertolongan.

"Tulung ... Tulung ... Tulung ...," terdengar seseorang sedang meminta tolong. Seharuk pun mencari sumber dari suara tersebut. Betapa terkejutnya Seharuk, ternyata ada orang yang hanyut terseret air di sungai Komering. Melihat kejadian itu, Seharuk langsung menceburkan diri membantu orang tersebut (Nurdin, 2021: 33-34).

Kutipan di atas menggambarkan sikap kepedulian sosial Seharuk terhadap sesama. Ia berkenan menolong seseorang yang membutuhkan pertolongan sekalipun Seharuk tidak mengenal orang tersebut. Hal itu menunjukkan bahwa nilai kepedulian sosial telah melekat kuat di dalam diri Seharuk.

Nilai kepedulian sosial juga melekat dalam diri tokoh Sangsri.

Setelah mendapatkan padi yang diinginkan, Sangsri langsung menanam padi tersebut serta membagikan hasil tanaman tersebut kepada penduduk yang membutuhkan. Mereka sangat senang dan gembira karena apa yang mereka tunggu-tunggu akhirnya terkabulkan juga. Penduduk di tepian Komering mendapatkan jatah beras berkat pertolongan Sangsri. (Nurdin, 2021: 33-34)

Data di atas menggambarkan kepedulian Sangsri kepada masyarakat yang sangat membutuhkan. Sangsri merupakan penyelamat bagi penduduk yang hidupnya kesusahan sehingga tidak mampu membeli bahan pokok untuk menyambung hidup sehari-hari.

\section{Optimisme}

Optimisme merupakan sikap atau pandangan hidup yang dalam segala hal dipandang kebaikannya saja (Suharso \& Retnoningsih, 2020: 345).

Seharuk dalam cerita juga digambarkan sebagai sosok yang tidak mudah berputus asa. Ia selalu optimis sekalipun keadaan hidupnya dalam keadaan terpuruk sekalipun. Hal ini dapat diketahui melalui kutipan berikut.

Tapi sayang sampai mentari berada di atas kepala. Seharuk masih belum bisa menghabiskan barang jualannya. Kalangan pun bubar. Tidak banyak barang dagangan yang laku terjual. Pada hari berikutnya, begitu juga barang dagangan Seharuk tidak banyak terjual. Ia harus bersusah payah berjalan dari kalangan ke rumahnya. Tapi Seharuk bukan orang yang gampang berputus asa. (Nurdin, 2021: 40)

Sikap optimisme dari Seharuk dapat dilihat melalui tekatnya yang tidak mudah berputus asa. Ia tetap berusaha sekalipun usaha yang dilakukan belum dapat membuahkan hasil yang maksimal. Seharuk terus memutar otaknya agar dagangannya dapat terjual semuanya. Berkat kegigihan dan keoptimisannya. Akhirnya Seharuk berhasil menjual semua barang dagangan yang dibawanya.

\section{Cinta Damai}

Cinta damai merupakan sikap yang mendorong dirinya untuk menghasilkan sesuatu yang berguna bagi masyarakat, dan mengakui, serta menghormati keberhasilan orang lain (Hartono, 2014: 263). 
Nilai moral tentang cinta damai digambarkan sosok Pasirah Kandil dan ketujuh anaknya. Mereka digambarkan dapat saling menerima setelah sebelumnya melakukan tindakan yang merusak ketenangan.

Pasairah meminta maaf kepada ketujuh anaknya dan mengajak mereka untuk pulang ke Lombahan Marga. Ketujuh anaknya pun menerima tawaran dari Pasirah Kandil. Mereka juga menyadari bahwa perbuatannya juga memang salah. Ketujuh anak pasirah berubah menjadi anak yang benarbenar menjadi harapan Pasirah. Hidup damai, aman, dan sejahtera di tepian Komering yang mengalir indah dan megah. (Nurdin, 2021: 62)

Kutipan di atas menggambarkan nilai cinta damai dari tokoh-tokoh cerita. Bermula dari sebuah pengakuan akan kesalahan dan kesanggupan meminta maaf, kedamaian keluarga pasirah Kandil benarbenar tercipta. Ketujuh putra yang awalnya sangat nakal dapat berubah menjadi anak yang bisa diharapkan. Mereka bertujuh juga mengakui bahwa selama ini sikap yang mereka tunjukkan telah melenceng jauh dari norma-norma yang berlaku di tengah masyarakat. Hadirnya kesadaran dari Pasirah Kandil dan juga ketujuh anaknya menciptakan kehidupan yang jauh lebih baik.

\section{Simpulan}

Berdasarkan hasil penelitian, dapat disimpulkan bahwa cerita rakyat Komering Seharuk mengandung beragam unsur budaya Komering dan nilai moral yang hendak disampaikan penulis kepada pembaca. Unsur budaya Komering yang terkandung dalam cerita rakyat Seharuk di antaranya adalah penggunaan bahasa Komering, pengangkatan lagu daerah Komering Umbai Akas, latar sungai Komering sebagai salah satu sumber kebudayaan masyarakat Komering, dan Tala Balak yang digunakan sebagai sarana penghancur kezaliman penguasa.

Adapun nilai moral yang terkandung dalam cerita rakyat Seharuk meliputi nilai kepatuhan, kebijaksanaan, bekerja keras, religiusitas, kesediaan bertanggung jawab, optimism, peduli sosial, dan cinta damai. Dengan demikian, cerita rakyat Komering Seharuk dapat dijadikan bahan bacaan yang positif karena kaya akan unsur-unsur budaya dan nilai moral yang dapat dijadikan motivasi dan pembelajaran dalam kehidupan sehari-hari.

\section{Daftar Pustaka}

Bastari, H. 2019. Negeri Para Phuyang: Hikayat Komering Pitu Phuyang. Kebumen: Intishar Publishing.

Chaplin. 2006. Dasar-Dasar Pendidikan Moral. Yogyakarta: Angkasa.

Danandjadja, J. 2007. Foklor Indonesia, Ilmu Gosip, Dongeng, dan lain-lain. Jakarta: Pustaka Utama Grafiti.

Departemen Pendidikan Nasional. 2014. Kamus Besar Bahasa Indonesia: Pusat Bahasa Edisi Keempat. Jakarta: Gramedia Pustaka Utama.

Dwiyanti, R., \& Suherman, A. 2019. Unsur Budaya dalam Cerita Film Cakra Buana Karya Sutradara Massimo Burhanuddin. Lokabasa, 10(2), 204-213. https://doi.org/10.17509/jlb.v10i2.21 361

Febriyanto, D., Nurjana, K., Anista, E., \& Mardiansyah, D. 2021. Kearifan Lokal dalam Hikayat Komering Pitu 
Phuyang. Diglosia: Jurnal Kajian Bahasa, Sastra, Dan Pengajarannya, 4, 321-334.

Febriyanto, D., \& Suryani, S. 2020. Analisis Struktural dan Nilai Moral Kumpulan Cerpen Tuhan buat Vasty Suntingan Asep Sambodja. Seulas Pinang: Jurnal Pendidikan Bahasa dan Sastra Indonesia, 2(1), 13-25. https:// doi.org/https:/ / doi.org/10.3 0599/spbs.v2i1.818

Gusnetti, G., Syofiani, S., \& Isnanda, R. 2015. Struktur Dan Nilai-Nilai Pendidikan Dalam Cerita Rakyat Kabupaten Tanah Datar Provinsi Sumatera Barat. Gramatika STKIP PGRI Sumatera Barat, 1(2), 183-192. https:// doi.org/10.22202/jg.2015.v1i2 .1238

Harmanti, M. H., Sobari, T., \& Abdurrokhman, D. 2020. Analisis Nilai-Nilai Pendidikan Karakter Pada Novel "9 Matahari" Karya Adenita. Parole: Jurnal Pendidikan Bahasa Dan Sastra Indonesia, 3(1), 183-194.

Hartono. 2014. Pendidikan Karakter dalam Kurikulum 2013. Jnana Budaya, 19(2), 259-268.

https:/ / doi.org/10.25273/ajsp.v2i2.14 58

Herdianawati, N., \& Isnaniah, S. 2020. Unsur Budaya dalam Kumpulan Cerpen Martabat Kematian Karya Muna Mastari sebagai Materi Ajar BIPA. Dialektika: Jurnal Bahasa, Sastra, dan Pendidikan Bahasa dan Sastra Indonesia, 7(2) (Februari), 117-135. https://doi.org/10.15408/dialektika.v $7 \mathrm{i} 2.12568$

Irawati, D. 2015. Unsur Budaya
Minangkabau dalam Novel Mencari Cinta yang Hilang Karya Abdul Karim Khiaratullah. Diksa, 1(2), 53-64. https:/ / doi.org/10.33369/ diksa.v1i2.3 180

Koentjaraningrat. 1990. Pengantar Ilmu Antropologi. Jakarta: Rineka Cipta.

Maulidiah, N., \& Saddhono, K. 2019. Wujud Budaya dan Nilai Pendidikan dalam Cerita Rakyat Putri Jelumpang: Sebuah Kajian Antropologi Sastra. Widyaparwa, 47(2), 185-192.

https:/ / doi.org/10.26499/wdprw.v47i 2.356

Mulyana, R. 2004. Mengartikulasikan Pendidikan Nilai. Bandung: Alfabeta.

Murti, S., \& Maryani, S. 2017. Analisis Nilai Moral Novel Bulan Jingga dalam Kepala Karya M. Fadjroel Rachman. Jurnal Kajian Bahasa, Sastra Dan Pengajarannya (KIBASP), 1(1), 50-61. https://doi.org/10.31539/kibasp.v1i1. 93

Nurdin, U. 2021. Seharuk. Kebumen: Intishar Publishing.

Nurgiyantoro, B. 2015. Teori Pengkajian Fiksi. Yogyakarta: Gajah Maja Universiti Press.

Pahruroji, P., Julianto, F., \& Lestari, R. D. 2019. Analisis Nilai Moral pada Cerpen " Misteri Uang Melayang " Karya Sona. Pendidikan Bahasa Dan Sastra Indonesia, 2 (September), 777782.

https://journal.ikipsiliwangi.ac.id

Rahmawati, S. S. 2006. Analisis Aktansial dan Fungsional Cerita Saga dalam Sastra 
Lisan Tolaki. Departemen Pendidikan Nasional Pusat Bahasa: Kantor Bahasa Sulawesi Tenggara.

Ratna, N. K. 2015. Teori, Metode, dan Teknik Penelitian Sastra. Yogyakarta: Pustaka Pelajar.

Rohmadi, M., \& Yakub, N. 2017. DasarDasar Penelitian Bahasa, Sastra, dan Pengajaran. Surakarta: Pustaka Briliant.

Sa'ida, N. 2020. Analisis Nilai Moral dalam Cerita Rakyat. Jurnal Pendidikan, Pengasuhan, Kesehatan Dan Gizi Anak Usia Dini (JP2KG AUD), 1(1), 47-54.

Suharso, S., \& Retnoningsih, A. 2020. Kamus Besar Bahasa Indonesia: Edisi Lux. Widya Karya.

Sukitman, T. 2016. Internalisasi Pendidikan Nilai dalam Pembelajaran (Upaya Menciptakan Sumber Daya Manusia yang Berkarakter). JURNAL JPSD (Jurnal Pendidikan Sekolah Dasar), 2(2), 85-96. https://doi.org/10.26555/jpsd.v2i2.a5 559

Sumarto. 2019. Budaya, Pemahaman dan Penerapannya "Aspek Sistem Religi, Bahasa, Pengetahuan, Sosial, Kesenian, dan Teknologi. Jurnal Literasiologi, 1(2), 144-159.

https:/ / doi.org/10.47783/literasiologi .v1i2.49

Tasmuji., dkk. 2011. Ilmu Alamiah Dasar, Ilmu Sosial Dasar, Ilmu Budaya Dasar. Surabaya: IAIN Sunan Ampel Press.

Triyanto. 2014. Pendidikan Seni Berbasis Budaya. Imajinasi: Jurnal Seni, 7(1), 3342.

Zakiyah, Q. Y., \& Rusdiana, H. A. 2014. Pendidikan Nilai: Kajian Teori dan Praktik di Sekolah. Bandung: Pustaka Setia. 